\title{
Feeding distillers dried grains in replacement of forage in limit-fed dairy heifer rations: Effects on growth performance, rumen fermentation, and total-tract digestibility of nutrients
}

\author{
A. K. Manthey, ${ }^{*}$ J. L. Anderson, ${ }^{* 1}$ and G. A. Perry† \\ *Dairy Science Department, and \\ †Department of Animal Science, South Dakota State University, Brookings 57007
}

\begin{abstract}
The objective of this study was to determine the effects of increasing dietary concentration of distillers dried grains (DDGS) in dairy heifer rations. A 16-wk randomized complete block design study was conducted using 48 Holstein heifers [199 $\pm 2 \mathrm{~d}$ of age; body weight (BW) $206 \pm 2 \mathrm{~kg}$ ] to evaluate effects of dietary treatment on dry matter (DM) intake, average daily gain, growth performance, rumen fermentation, and nutrient digestibility. Treatments were (1) $30 \%$ DDGS with the diet fed at $2.65 \%$ of BW, (2) $40 \%$ DDGS with the diet fed at $2.50 \%$ of BW, and (3) $50 \%$ DDGS with the diet fed at $2.35 \%$ of BW. The remainder of the diet consisted of grass hay and $1.5 \%$ mineral mix. Heifers were individually limit-fed using Calan gates. Heifers were weighed every 2 wk and the ration amount offered was adjusted accordingly. Frame measurements and body condition score were recorded every 2 wk. Rumen fluid was collected via esophageal tubing during wk 12 and 16 for $\mathrm{pH}$, ammonia $\mathrm{N}$, and volatile fatty acid analysis. Total-tract digestibility of nutrients was evaluated during wk 16 using fecal grab sampling. No treatment by week interactions were found for any of the growth parameters measured, and growth parameters did not differ among treatments. Heifer DM intake linearly decreased with increasing concentrations of DDGS. Body weight and average daily gain were similar among treatments, whereas gain:feed linearly increased across treatments, with a tendency for a treatment by time interaction. As the dietary concentrations of DDGS increased, rumen ammonia $\mathrm{N}$ linearly increased. Acetate proportion and acetate:propionate linearly decreased as DDGS increased, whereas propionate linearly increased. There were treatment by time interactions for propionate proportion and acetate:propionate. Increasing dietary concentrations of DDGS linearly increased total-tract digestibility of DM, organic matter, and
\end{abstract}

Received December 20, 2015.

Accepted June 2, 2016.

${ }^{1}$ Corresponding author: jill.anderson@sdstate.edu crude protein. Limit-feeding diets with greater concentrations of DDGS improved gain:feed and total-tract digestibility of DM and crude protein, and maintained frame growth without increasing body condition score. Results demonstrated that replacing forage with DDGS at up to a $50 \%$ inclusion rate in limit-fed rations can maintain heifer growth performance.

Key words: distillers grains, dairy heifer, growth performance

\section{INTRODUCTION}

Previous research has demonstrated that feeding dried distillers grains with solubles (DDGS) improves feed efficiency in ruminants (Anderson et al., 2006; Klopfenstein et al., 2008; Schingoethe et al., 2009). The increased concentrations of fermentable fiber and rumen undegradable protein found in DDGS compared with other feed sources such as corn and soybean meal are thought to be the factors of the improvement in animal production (Schingoethe et al., 2009). Feeding DDGS has been well researched in beef heifers (Klopfenstein et al., 2008); however, relatively little research focuses on feeding distillers grains to growing dairy heifers. Previous research has found that distillers wet grains with solubles ensiled with soyhulls or corn stalks when fed in ad libitum rations to dairy heifers increased ADG compared with control diets (Anderson et al., 2009, 2015c). Diets with full-fat DDGS or low-fat DDGS, included at approximately 20 or $30 \%$ of DM, have also been demonstrated to maintain ADG and overall growth performance in dairy heifers compared with control diets containing corn and soybean meal when fed ad libitum (Schroer et al., 2014) or limit fed (Anderson et al., 2015a).

Diets typically used for limit-feeding are proportionately high in concentrates and are more nutrient dense, allowing an increase in energy and nutrient utilization efficiency while decreasing nutrient loss in fecal matter (Zanton and Heinrichs, 2007). However, we are not aware of any research that examined the effect of DDGS as the primary concentrate ingredient in limit- 
fed dairy heifer diets. Therefore, the main objective of this study was to determine the effects on growth performance when DDGS was fed as the major concentrate ingredient at greater proportions of the diet than previously researched. Secondary objectives were to determine the effects of diets on rumen fermentation and total-tract digestibility. Additionally, limit-feeding was implemented to avoid excessive ADG that could be caused by increased dietary proportion of DDGS. We hypothesized that increasing the dietary concentration of DDGS would maintain heifer growth performance due to limit-feeding and there would be changes in rumen fermentation as DDGS replaced forage in the diets. We also hypothesized that gain:feed and nutrient utilization would increase with increasing concentrations of DDGS.

\section{MATERIALS AND METHODS}

All procedures and animal use were approved before the start of the feeding study by the South Dakota Institutional Animal Care and Use Committee.

\section{Experimental Design}

Forty-eight Holstein heifers $(199 \pm 2$ d of age; 206 $\pm 2 \mathrm{~kg}$ ) were used in a randomized complete block design with 3 treatment diets. Heifers were blocked in groups of 3 , based on birth date and BW. Heifers were randomly assigned to treatment within blocks. Heifers were added to the study based on farm calving rates and were introduced in multiples of 6 with a target age of 7 mo. Heifers were acclimated to the barns and feeding system for approximately 2 wk followed by an experimental feeding period of $16 \mathrm{wk}$.

Treatment diets (Table 1) were (1) 30\% DDGS with the diet fed at $2.65 \%$ of BW (30DG), (2) $40 \%$ DDGS with the diet fed at $2.50 \%$ of BW (40DG), and (3) $50 \%$ DDGS with the diet fed at $2.35 \%$ of BW (50DG) on a DM basis. The remainder of the diets consisted of grass hay and $1.5 \%$ mineral mix. Diets were formulated using the NRC (2001) to meet a target ADG of $0.8 \mathrm{~kg} / \mathrm{d}$ when fed to a $250 \mathrm{~kg}$ of BW Holstein heifer and to provide similar energy intakes. The $250 \mathrm{~kg}$ of BW was a pre-estimated average BW for heifers during the study based on age and herd data. On the last 2 $\mathrm{d}$ of each 2-wk interval, heifers were weighed and the amount of feed offered was determined for the next 2 wk. Amount of each ration offered was also adjusted using DM analysis of feedstuffs.

To avoid variation in production within plant and over time, DDGS was purchased in 2 batches, one at the beginning of the experiment, and a second batch half way through the study and stored at the South
Dakota State University feed mill. Hay was purchased in 2 batches and an effort was made to match the nutrient composition between batches.

\section{Animal Care and Feeding}

This study was conducted at the South Dakota State University Dairy Research and Training Facility (Brookings, SD). The study was completed from September 2013 through September 2014 to accommodate available animals and pen space. Heifers were observed daily for health problems and treated according to routine management practices at the Dairy Research and Training Facility.

Heifers were housed in pens of 6 heifers each. Each pen had an inside roofed area $(7 \mathrm{~m} \times 4 \mathrm{~m})$ and an outside dirt exercise lot $(7 \mathrm{~m} \times 23.5 \mathrm{~m})$. The inside areas of the pens were a bedded pack, and were bedded with straw once every 2 wk. Because the consumption of bedding material can be a concern when limit-feeding, pens were only bedded once every 2 wk. Each pen was provided with water ad libitum. Heifers were fed once daily at $0830 \mathrm{~h}$ using the Calan gate feeding system (American Calan Inc., Northwood, NH) and individual intakes were measured. Bales of hay were coarsely preground with a vertical tub grinder to ease hand mixing. Diet components were individually weighed and hand mixed for each heifer. The mineral mix was mixed with the DDGS before mixing with the grass hay. Because heifers were limit-fed and were expected to consume all feed, particle sorting was a minor concern. Any orts were weighed and recorded every morning before feeding. Samples of DDGS and grass hay were taken each week and stored at $-20^{\circ} \mathrm{C}$ until analysis.

Table 1. Ingredient composition of treatment diets with increasing inclusion amounts of distillers dried grains with solubles (DDGS) in replacement of forage fed to growing replacement dairy heifers

\begin{tabular}{lccc}
\hline & \multicolumn{3}{c}{ Treatment $^{2}$} \\
\cline { 2 - 4 } Ingredient, ${ }^{1} \%$ of DM & $30 \mathrm{DG}$ & 40DG & $50 \mathrm{DG}$ \\
\hline DDGS & 30.0 & 40.0 & 50.0 \\
Grass hay & 68.5 & 58.5 & 48.5 \\
Vitamin and mineral premix & 0.75 & 0.75 & 0.75 \\
Limestone & 0.30 & 0.30 & 0.30 \\
Sodium bicarbonate & 0.30 & 0.30 & 0.30 \\
Salt & 0.15 & 0.15 & 0.15 \\
\hline
\end{tabular}

${ }^{1}$ Formulated using NRC, 2001.

${ }^{2} 30 \%$ dietary inclusion rate of DDGS (30DG), $40 \%$ dietary inclusion rate of DDGS (40DG), 50\% dietary inclusion rate of DDGS (50DG).

${ }^{3}$ Contained $2.2 \mathrm{~g} / \mathrm{kg}$ of lasalocid, $14.5 \% \mathrm{Ca}, 8.0 \% \mathrm{P}, 21.0 \% \mathrm{NaCl}, 2.5 \%$ $\mathrm{Mg}, 1.5 \% \mathrm{~K}, 2.0 \% \mathrm{~S}, 4,100 \mathrm{mg} / \mathrm{kg}$ of $\mathrm{Mn}, 1,250 \mathrm{mg} / \mathrm{kg}$ of Cu, $70 \mathrm{mg} /$ $\mathrm{kg}$ of Co, $70 \mathrm{mg} / \mathrm{kg}$ of I, $53 \mathrm{mg} / \mathrm{kg}$ of Se, $5,500 \mathrm{mg} / \mathrm{kg}$ of Zn, $325 \mathrm{mg} /$ $\mathrm{kg}$ of $\mathrm{Fe}, 704,000 \mathrm{IU} / \mathrm{kg}$ of vitamin $\mathrm{A}, 140,800 \mathrm{IU} / \mathrm{kg}$ of vitamin $\mathrm{D}_{3}$, and $5,280 \mathrm{IU} / \mathrm{kg}$ of vitamin E (Future Cow Supreme Premix B2000, Land O'Lakes Inc., St. Paul, MN). 


\section{Animal Measurements and Sampling}

Body growth measurements including BW, withers and hip heights, heart and paunch girth, body length, and hip width were measured on 2 consecutive days approximately $4 \mathrm{~h}$ postfeeding at the beginning of the study and then every 2 wk thereafter for the remainder of the study. Body length was measured from the top point of the withers to the end of the ischium (Hoffman, 1997). Body condition score was assessed at the start of the experiment and then every 2 wk thereafter for the remainder of the study by 3 independent observers based on the scale described by Wildman et al. (1982) with $1=$ emaciated and $5=$ obese. Rumen fluid was sampled from each heifer on 2 consecutive days during wk 12 and 16 approximately $4 \mathrm{~h}$ postfeeding via esophageal tubing. After discarding the first 200 $\mathrm{mL}$ of fluid to minimize saliva contamination, approximately $50 \mathrm{~mL}$ of rumen fluid was collected. Samples were immediately measured for $\mathrm{pH}$ using a $\mathrm{pH}$ meter (Waterproof pH Testr 30, Oakton Instruments, Vernon Hills, IL) and 2 aliquots $(10 \mathrm{~mL})$ were acidified with either $200 \mu \mathrm{L}$ of $50 \%$ (vol/vol) sulfuric acid or $2 \mathrm{~mL}$ of $25 \%$ (wt/vol) metaphosphoric acid and stored at $-20^{\circ} \mathrm{C}$ until later analyses of ammonia $\mathrm{N}\left(\mathrm{NH}_{3}-\mathrm{N}\right)$ and VFA analysis, respectively.

For analysis of total-tract digestibility, fecal samples were collected during wk 16 of the feeding period. Acid detergent insoluble ash was used as an internal digestibility marker. Orts and fecal grab samples were collected during 3 consecutive days in wk 16 and stored at $-20^{\circ} \mathrm{C}$ until processing and analysis. Fecal sampling time points were scheduled so that the samples represented every $3 \mathrm{~h}$ in a 24 -h feeding cycle.

\section{Laboratory Analysis}

Total dietary nutrient concentrations were calculated based on analysis of grass hay and DDGS for each treatment. Feed samples were dried for $24 \mathrm{~h}$ at $105^{\circ} \mathrm{C}$ for DM analysis to adjust dietary ingredient inclusion rates and determine DMI. Samples of DDGS and grass hay were collected once weekly and frozen at $-20^{\circ} \mathrm{C}$ until analysis. Samples of DDGS and grass hay were thawed and samples from 4 consecutive weeks were composited on an as-fed basis by weight. Composite samples were dried in duplicate for $48 \mathrm{~h}$ at $55^{\circ} \mathrm{C}$ in a Despatch oven (Style V-23, Despatch Oven Co., Minneapolis, MN), ground to 4-mm particle size with a Wiley Mill (model 3, Arthur H. Thomas Co., Philadelphia, $\mathrm{PA}$ ), and then further ground to 1-mm particle size using an ultracentrifuge mill (Brinkman Instruments Co., Westbury, NY). To correct analysis to $100 \%$ DM, 1-g aliquots of feed samples were dried for $4 \mathrm{~h}$ in a $105^{\circ} \mathrm{C}$ oven. Ash content was determined by incinerating a 1-g sample for $8 \mathrm{~h}$ at $450^{\circ} \mathrm{C}$ in a muffle furnace (AOAC International, 2002, method 942.05). Organic matter was calculated as $\mathrm{OM}=(100-\%$ ash $)$. Samples were analyzed for nitrogen content via Dumas combustion analysis (AOAC International, 2002, method 968.06), on a Rapid N Cube (Elementar Analysensysteme, GmbH, Hanau, Germany). Nitrogen content was then multiplied by 6.25 to calculate CP. Neutral detergent fiber (Van Soest et al., 1991) and ADF (Robertson and Van Soest, 1981) were analyzed sequentially using the Ankom 200 fiber analysis system (Ankom Technology Corp., Fairport, NY). For NDF, heat-stable $\alpha$-amylase and sodium sulfite were used. Diethyl ether and petroleum ether were used in separate analyses to determine ether extract (EE; AOAC International, 2002, method 920.39) in an Ankom XT10 fat analysis system (Ankom Technology Corp.). Analysis was conducted using both solvents because differences in polarity between the solvents results in different extraction values. Diethyl ether is the recommended solvent for most animal feeds. Because diethyl ether tends to overestimate EE in DDGS, petroleum ether is the recommended solvent for EE analysis (Thiex, 2009). Nonfibrous carbohydrate was calculated as $\% \mathrm{NFC}=100-(\%$ ash $+\% \mathrm{CP}+$ $\% \mathrm{NDF}+\% \mathrm{EE}$ ) according to the NRC (2001).

Dried and ground samples of grass hay and DDGS were further composited into 4 or 5 mo composites and sent to a commercial laboratory (Dairyland Laboratories Inc., Arcadia, WI) for analysis of minerals (Ca, $\mathrm{Cl}, \mathrm{Mg}, \mathrm{P}, \mathrm{K}, \mathrm{Na}, \mathrm{S}, \mathrm{Fe}, \mathrm{Mn}, \mathrm{Mo}$, and Zn) and starch. Mineral content, excluding chloride, was determined using inductively coupled plasma spectroscopy (AOAC International, 1995). Chloride content was determined using a direct reading chloride analyzer (Corning 926, Corning Inc., Corning, NY). Starch was analyzed using a modified procedure analyzing glucose using YSI Biochemistry Analyzer (YSI Inc., Yellow Springs, OH; Bach Knudsen, 1997).

Rumen fluid samples preserved with sulfuric acid were thawed and centrifuged at $30,000 \times g$ for $20 \mathrm{~min}$ at $4^{\circ} \mathrm{C}$ (Centrifuge: Eppendorf 5403, Eppendorf North America, Hauppauge, NY) and analyzed for ammonia $\mathrm{N}$ using a colorimetric assay performed on a microplate spectrophotometer (Cary 50, Varian Inc., Walnut Creek, CA) according to Chaney and Marbach (1962). Rumen fluid samples that were preserved with metaphosphoric acid were thawed and centrifuged at 30,000 $\times g$ for $20 \mathrm{~min}$ at $4^{\circ} \mathrm{C}$ and analyzed for acetate, propionate, butyrate, isobutyrate, isovalerate, and valerate concentrations using an automated GC (model 6890, Hewlett-Packard Co., Palo Alto, CA) using a flameionization detector. Volatile fatty acids were separated on a capillary column $(15 \mathrm{~m} \times 0.25 \mathrm{~mm}$ i.d.; Nukol, 
17926-01C; Supelco Inc., Bellefonte, PA) using 2-ethylbutyrate as an internal standard. The split ratio of 100:1 in the injector port was at a temperature of $250^{\circ} \mathrm{C}$ with flow rate of $1.3 \mathrm{~mL} / \mathrm{min}$ of helium. The column and detector temperature were maintained at 140 and $250^{\circ} \mathrm{C}$, respectively.

Fecal and orts samples for each heifer were composited on an as-is basis by volume. Aliquots of $100 \mathrm{~mL}$ of fecal samples were taken from each time point and composited. Available orts were collected each day during the collection period. Orts were composited based on proportions of weight from each day for the few heifers that had orts on multiple days. Samples were then dried and ground as previously described for feed samples. Fecal samples were analyzed for DM, ash, CP, NDF, and ADF as previously described for feed samples. Acid detergent insoluble ash analysis was conducted on all feed composites, fecal samples, and orts. The method for acid detergent insoluble ash analysis consists of analyzing the sample for ADF content (Robertson and Van Soest, 1981) and then determining the ash content using a modified procedure of AOAC method 935.29 (AOAC International, 2002). Digestibility calculations were determined according to Merchen (1988).

\section{Statistical Analysis}

All data were analyzed using SAS version 9.4 (SAS Institute Inc., Cary, NC). The MEANS procedure of SAS was used to estimate the means and standard errors of the nutrients of the monthly feed composites.

Heifer intake, growth data, and rumen fermentation parameters were analyzed as a randomized complete block design with week as the repeated measure and the term heifer (block) as the subject using the PROC MIXED procedures of SAS (Littell et al., 2006). The model included treatment, week, and treatment $\times$ week interactions. Initial body size measurements and BW were included as covariates within the model. Akaike's criterion was used to determine the most suitable covariance structure in repeated measures for each parameter. Covariance structures tested were compound symmetry, first-order autoregressive, Toeplitz, and unstructured. Compound symmetry resulted in the least absolute Akaike's values and was used for the final model. Significant differences among treatments were declared at $P \leq 0.05$ and tendencies were declared at $0.05<P \leq 0.10$. Linear and quadratic effects of treatments were analyzed using orthogonal contrasts.

Regression procedures of SAS were used to determine average change per day for ADG and body frame measurements. The $P$-values for the interaction of treatment and time using MIXED analysis were used to determine significance of change per day among treatments (Kut- ner et al., 2004). Gain-to-feed ratio was calculated as the ratio of ADG (slope of BW regression) to DMI for each treatment. For comparison of analyses, ADG and gain:feed were also calculated based on 2-wk interval data and analyzed using MIXED procedures with repeated measures similar to frame size parameters.

The MIXED procedures of SAS were used for the analysis of total-tract digestibility of nutrients. The model included treatment with block included as a random variable because samples were analyzed from a single time period.

\section{RESULTS AND DISCUSSION}

\section{Feed Analysis}

The nutrient composition of the individual ingredients used in the experimental diets is presented in Table 2. Because the DDGS was purchased in 2 large batches, nutrient composition of the DDGS did not vary much over the duration of the study; however, there was some variation in the nutrient composition of the grass hay during the experiment.

Average nutrient composition of the experimental diets is presented in Table 3. The nutrient composition was based on individual ingredient analysis during the course of the study. The dietary $\mathrm{CP}$ concentration increased with increasing concentrations of DDGS as expected due to experimental design. The EE concentrations of the diets increased with increasing concentrations of DDGS. Concentration of NDF decreased with increasing concentrations of DDGS. Experimental

Table 2. Nutrient composition of the grass hay and distillers dried grains with solubles (DDGS) used in the treatment diets fed to growing dairy heifers

\begin{tabular}{|c|c|c|c|c|}
\hline \multirow[b]{2}{*}{ Item $^{1}$} & \multicolumn{2}{|c|}{ Grass hay } & \multicolumn{2}{|c|}{ DDGS } \\
\hline & Mean & $\mathrm{SE}$ & Mean & SE \\
\hline $\mathrm{DM}^{2} \%$ & 86.3 & 0.31 & 86.9 & 0.35 \\
\hline $\mathrm{Ash}^{2}$ & 8.76 & 0.328 & 4.68 & 0.037 \\
\hline $\mathrm{OM}^{2}$ & 91.2 & 0.33 & 95.3 & 0.03 \\
\hline $\mathrm{CP}^{2}$ & 9.81 & 0.417 & 33.6 & 0.18 \\
\hline $\mathrm{ADF}^{2}$ & 37.8 & 0.50 & 10.0 & 0.35 \\
\hline $\mathrm{NDF}^{2}$ & 66.4 & 0.62 & 29.8 & 0.38 \\
\hline $\mathrm{EE}(\text { diethyl })^{2}$ & 1.87 & 0.101 & 12.9 & 0.13 \\
\hline $\mathrm{EE}$ (petroleum) ${ }^{2}$ & 1.05 & 0.102 & 7.80 & 0.079 \\
\hline $\mathrm{NFC}^{2,3}$ & 14.0 & 0.90 & 24.1 & 0.33 \\
\hline $\mathrm{Starch}^{4}$ & 0.84 & 0.033 & 6.00 & 0.041 \\
\hline $\mathrm{Ca}^{4}$ & 0.37 & 0.053 & 0.07 & 0.003 \\
\hline $\mathrm{P}^{4}$ & 0.20 & 0.028 & 0.86 & 0.017 \\
\hline $\mathrm{S}^{4}$ & 0.15 & 0.009 & 0.73 & 0.007 \\
\hline
\end{tabular}

${ }_{1} \%$ of DM, unless otherwise indicated.

${ }^{2}$ Results from analysis of monthly composites $(\mathrm{n}=13)$.

${ }^{3} \%$ of $\mathrm{NFC}=100-(\%$ ash $+\% \mathrm{CP}+\% \mathrm{NDF}+\% \mathrm{EE})(\mathrm{NRC}, 2001)$. $\mathrm{EE}=$ ether extract

${ }^{4}$ Results from analysis of 4 - or 5 -mo composites $(\mathrm{n}=4)$. 
diets had greater NDF than formulated due to changes in grass hay quality during the study. Starch concentration increased with increasing dietary concentration of DDGS; however, starch concentrations were very low across all diets. Therefore, the other nutrients including fat, fiber, and protein rather than starch were the major energy sources in the diets and we speculate that some protein was used as gluconeogenic precursor (Fahey and Berger, 1988). As the concentration of DDGS in the diet increased, energy density of rations increased, justifying the use of limit-feeding to avoid overconsumption and high ADG as seen by Anderson et al. $(2009,2015 \mathrm{c})$.

Differences in nutrient composition of the diets were further reflected in nutrient intakes (Table 4). Crude protein, EE, starch, and sulfur intake increased with increasing concentration of DDGS; however, NDF intake decreased. Sulfur intake increased across treatments; however, sulfur toxicity, which can occur when feeding large amounts of DDGS (Schingoethe et al., 2009), was not an issue in this study. Sodium bicarbonate and limestone were included in the experimental diets for buffering and to mitigate any risk of sulfur toxicity. Ad- ditionally, water supplied to heifers was from a municipal water treatment plant and had low sulfate concentration (approximately $140 \mathrm{mg} / \mathrm{L}$ ). Despite differences in nutrient composition and intake among treatments, $\mathrm{ME}$ and $\mathrm{NE}_{\mathrm{g}}$ intakes were similar among treatments, which is consistent with similar ADG (Table 5). Actual intakes as a percentage of BW (Table 5) were less than the prescribed feeding rate. Despite being limit-fed, heifers did have some orts, especially in the few days directly following ration increases. Additionally, heifers were weighed and then amount of feed offered was determined for the next $2 \mathrm{wk}$, so as heifers were always gaining weight daily the DMI as a percentage of BW was constantly decreasing during the 14-d intervals.

\section{Heifer Performance}

Body weight, DMI, and gain:feed results are presented in Table 5. The BW and ADG found via regression and based on 2-wk interval calculations were similar among treatments. The ADG in this experiment was greater than the target recommendation of $0.8 \mathrm{~kg} / \mathrm{d}$ (Zanton and Heinrichs, 2005). Because this research

Table 3. Nutrient composition of treatment diets with increasing inclusion amounts of distillers dried grains with solubles (DDGS) in replacement of grass hay fed to growing dairy heifers

\begin{tabular}{|c|c|c|c|c|c|c|}
\hline \multirow[b]{3}{*}{ Item $^{1}$} & \multicolumn{6}{|c|}{ Treatment $^{2}$} \\
\hline & \multicolumn{2}{|c|}{$30 \mathrm{DG}$} & \multicolumn{2}{|c|}{$40 \mathrm{DG}$} & \multicolumn{2}{|c|}{$50 \mathrm{DG}$} \\
\hline & Mean & $\mathrm{SE}$ & Mean & $\mathrm{SE}$ & Mean & $\mathrm{SE}$ \\
\hline$\overline{\mathrm{DM}},{ }^{3} \%$ & 86.7 & 0.29 & 86.7 & 0.29 & 86.8 & 0.29 \\
\hline $\mathrm{OM}^{3}$ & 91.1 & 0.23 & 91.5 & 0.19 & 91.9 & 0.16 \\
\hline $\mathrm{Ash}^{3}$ & 8.83 & 0.226 & 8.42 & 0.194 & 8.02 & 0.162 \\
\hline $\mathrm{CP}^{3}$ & 16.8 & 0.32 & 19.2 & 0.29 & 21.5 & 0.26 \\
\hline $\mathrm{ADF}^{3}$ & 28.9 & 0.41 & 26.1 & 0.39 & 23.3 & 0.37 \\
\hline $\mathrm{NDF}^{3}$ & $\begin{array}{l}20.9 \\
54.4\end{array}$ & 0.47 & $\begin{array}{l}20.1 \\
50.8\end{array}$ & 0.43 & 47.1 & 0.40 \\
\hline EE $(\text { diethyl) })^{3}$ & 5.17 & 0.077 & 6.27 & 0.076 & 7.38 & 0.078 \\
\hline $\mathrm{EE}$ (petroleum) $)^{3}$ & 3.06 & 0.073 & 3.74 & 0.066 & 4.41 & 0.062 \\
\hline $\mathrm{NFC}^{3,4}$ & 16.8 & 0.63 & 17.8 & 0.55 & 18.9 & 0.47 \\
\hline Forage $\mathrm{NDF}^{3}$ & 45.5 & 0.42 & 38.8 & 0.36 & 32.2 & 0.30 \\
\hline Nonforage $\mathrm{NDF}^{3}$ & 8.95 & 0.114 & 11.9 & 0.15 & 14.9 & 0.19 \\
\hline Starch $^{5}$ & 2.38 & 0.022 & 2.89 & 0.020 & 3.41 & 0.021 \\
\hline $\mathrm{Ca}^{5}$ & 0.28 & 0.036 & 0.25 & 0.031 & 0.22 & 0.025 \\
\hline $\mathrm{P}^{5}$ & 0.40 & 0.015 & 0.47 & 0.010 & 0.54 & 0.006 \\
\hline $\mathrm{Mg}^{5}$ & 0.21 & 0.005 & 0.23 & 0.004 & 0.25 & 0.003 \\
\hline $\mathrm{K}^{5}$ & 1.70 & 0.191 & 1.61 & 0.159 & 1.52 & 0.127 \\
\hline$S^{5}$ & 0.33 & 0.004 & 0.38 & 0.003 & 0.44 & 0.002 \\
\hline $\mathrm{Na}^{5}$ & 0.03 & 0.005 & 0.03 & 0.004 & 0.03 & 0.003 \\
\hline $\mathrm{Cl}^{5}$ & 0.48 & 0.083 & 0.44 & 0.072 & 0.40 & 0.061 \\
\hline $\mathrm{ME},{ }^{6} \mathrm{Mcal} / \mathrm{kg}$ of DM & 2.27 & - & 2.39 & - & 2.51 & - \\
\hline $\mathrm{NE}_{\mathrm{G}}{ }^{6} \mathrm{Mcal} / \mathrm{kg}$ of $\mathrm{DM}$ & 0.81 & - & 0.90 & - & 0.99 & - \\
\hline \multicolumn{7}{|c|}{${ }_{1 \%} \%$ of DM, unless otherwise indicated. } \\
\hline \multirow{2}{*}{\multicolumn{7}{|c|}{$\begin{array}{l}{ }^{2} 30 \% \text { dietary inclusion rate of DDGS (30DG), } 40 \% \text { dietary inclusion rate of DDGS (40DG), } 50 \% \text { dietary inclu } \\
\text { sion rate of DDGS (50DG). }\end{array}$}} \\
\hline & & & & & & \\
\hline \multicolumn{7}{|c|}{${ }^{3}$ Results from analysis of monthly composites $(\mathrm{n}=13)$} \\
\hline \multicolumn{7}{|c|}{${ }^{4} \% \mathrm{NFC}=100-(\%$ ash $+\% \mathrm{CP}+\% \mathrm{NDF}+\% \mathrm{EE})(\mathrm{NRC}, 2001) . \mathrm{EE}=$ ether extract. } \\
\hline \multicolumn{7}{|c|}{${ }^{5}$ Results from analysis of 4 - or 5 -mo composites $(n=3)$. } \\
\hline
\end{tabular}


Table 4. Mean nutrient intakes (kg/d unless otherwise noted) for heifers fed increasing inclusion amounts of distillers dried grains with solubles (DDGS) in replacement of grass hay

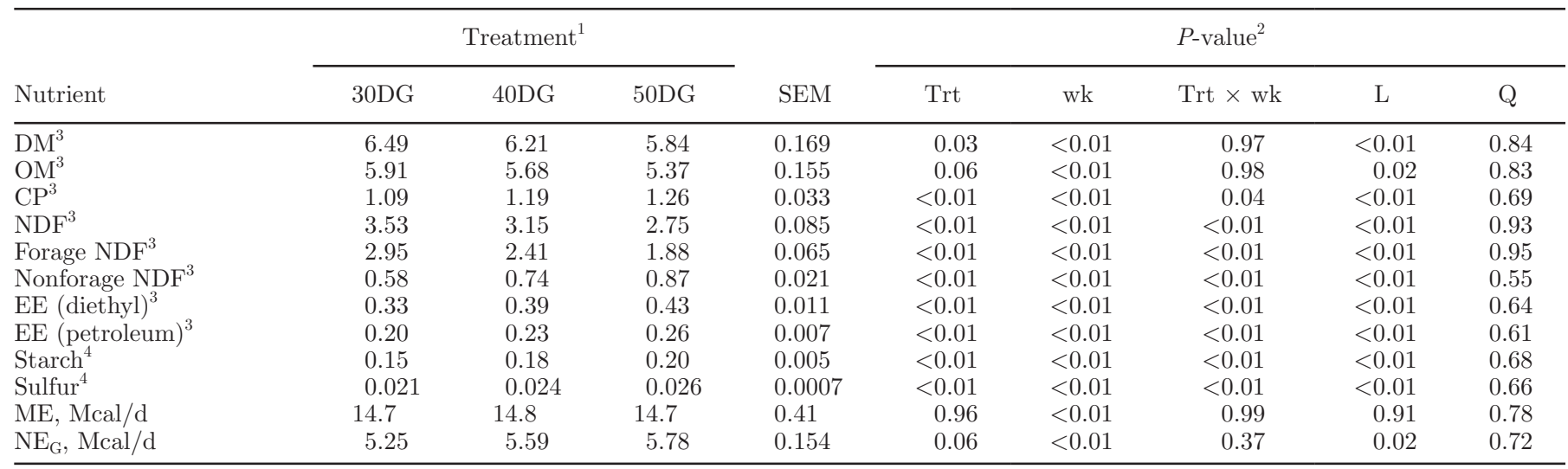

${ }^{1} 30 \%$ dietary inclusion rate of DDGS (30DG), 40\% dietary inclusion rate of DDGS (40DG), 50\% dietary inclusion rate of DDGS (50DG).

${ }^{2}$ Significance of effects for treatment $($ Trt $)$, week $(w k)$, treatment $\times$ week (Trt $\times$ wk), and linear $(\mathrm{L})$ and quadratic $(\mathrm{Q})$ orthogonal contrasts.

${ }^{3}$ Results from analysis of monthly composites $(\mathrm{n}=13)$. $\mathrm{EE}=$ ether extract.

${ }^{4}$ Results from analysis of 4 - or 5 -mo composites $(\mathrm{n}=3)$.

was intended to build upon the research conducted by Anderson et al. (2015a,b), the NRC (2001) model was used to formulate the diets. The results from this experiment and Anderson et al. (2015a,c) suggest that the NRC (2001) model overestimates the energy requirements of growing dairy heifers or underestimates energy provided by DDGS. The current experiment and Anderson et al. (2015a,c) demonstrate that heifers can be limit-fed diets with DDGS to control ADG, but amounts offered should be less than NRC (2001) recommendations.

Dry matter intake decreased and gain:feed from regression analysis and calculated based on 2-wk intervals (Table 5) increased across treatments. Nutrient density of the diet increased with increased DDGS; therefore, less feed was required to achieve similar ADG. This difference in DMI and gain:feed is consistent with previous experiments that controlled the nutrient intake in

Table 5. Dry matter intake, BW, and gain:feed ratios for heifers fed increasing inclusion amounts of distillers dried grains with solubles (DDGS) in replacement of grass hay

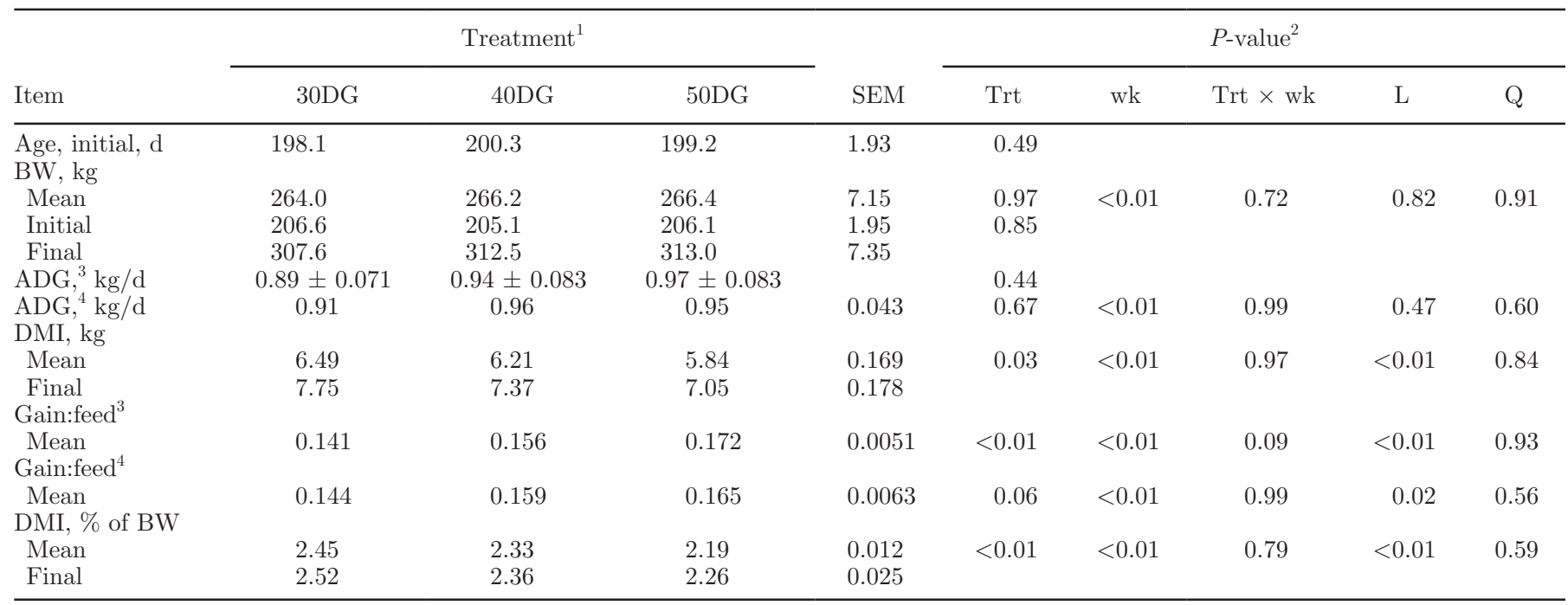

${ }^{1} 30 \%$ dietary inclusion rate of DDGS (30DG), 40\% dietary inclusion rate of DDGS (40DG), 50\% dietary inclusion rate of DDGS (50DG).

${ }^{2}$ Significance of effects for treatment (Trt), week (wk), treatment $\times$ week (Trt $\times$ wk), and linear (L) and quadratic (Q) orthogonal contrasts. ${ }^{3}$ Calculated using regression analysis of BW over the day of the study.

${ }^{4}$ Calculated based on change per 2 -wk intervals. 
Table 6. Frame size measurements for heifers fed treatment diets with increasing inclusion amounts of distillers dried grains with solubles (DDGS) in replacement of grass hay

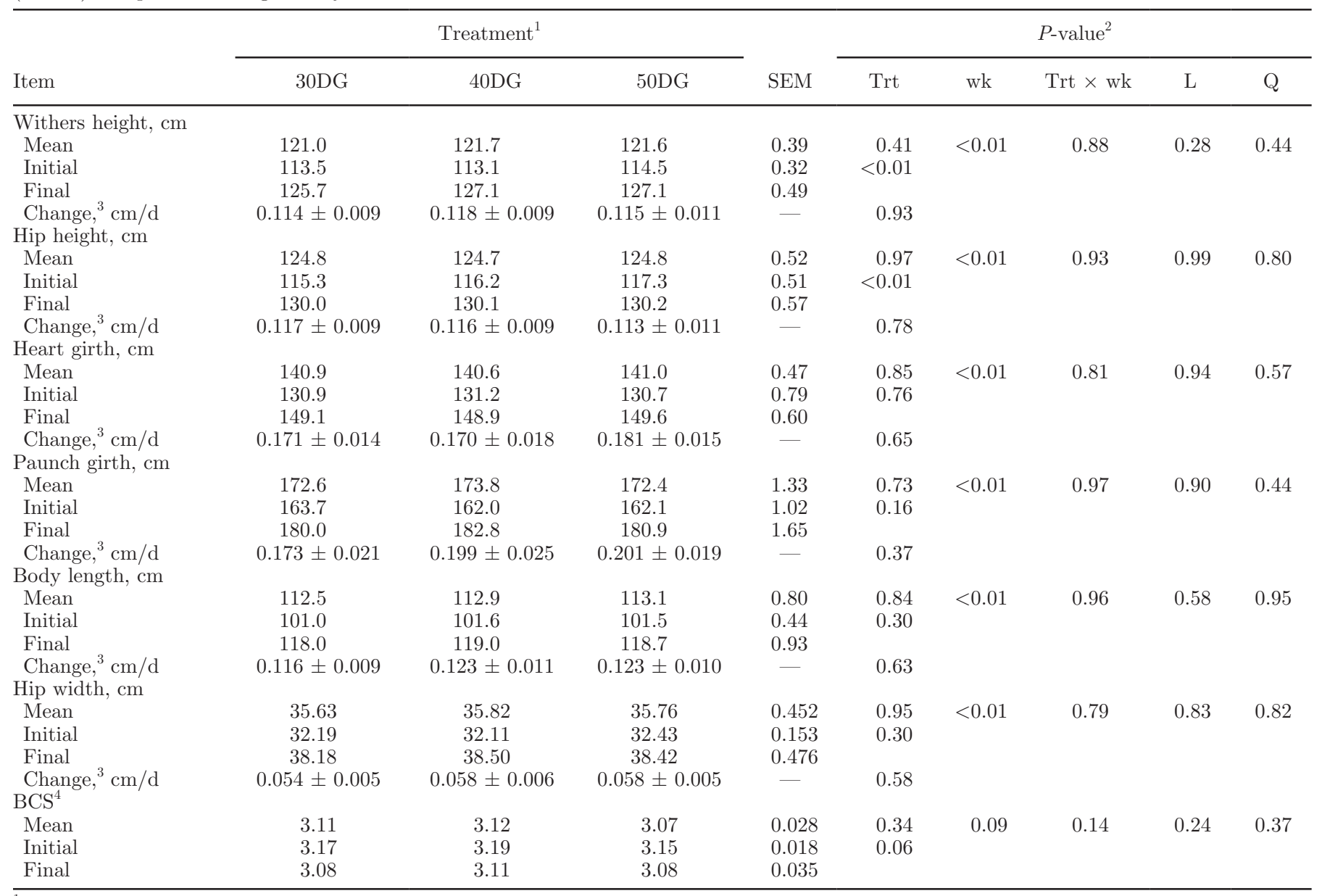

${ }^{1} 30 \%$ dietary inclusion rate of DDGS (30DG), 40\% dietary inclusion rate of DDGS (40DG), 50\% dietary inclusion rate of DDGS (50DG).

${ }^{2}$ Significance of effects for treatment (Trt), week (wk), treatment $\times$ week (Trt $\times$ wk), and linear $(\mathrm{L})$ and quadratic $(\mathrm{Q})$ orthogonal contrasts.

${ }^{3}$ Calculated using regression analysis of body measurement over the days of the study.

${ }^{4}$ Body condition score with $1=$ emaciated and $5=$ obese (Wildman et al., 1982).

diets differing in forage concentration (Hoffman et al., 2007; Lascano and Heinrichs, 2009; Zanton and Heinrichs, 2009). As originally hypothesized, 50DG had the greatest gain:feed and it linearly decreased with greater proportion of forage.

Frame size measurements and BCS are presented in Table 6. Based on genomic data, heifers had similar predicted transmitting ability for type composite score $(1.25,1.09$, and 1.20 for 30DG, 40DG, and 50DG, respectively, $\mathrm{SEM}=0.107, P=0.57)$; therefore, it was not used as a covariate term for growth performance. No treatment by week effects were found for any of the frame growth parameters measured. Frame size measurements increased over time, but no differences were found among treatments. There were also no differences in change per day for any of the frame growth measurements, suggesting that all treatment diets provided adequate metabolizable energy and protein to maintain growth during the experimental period. There were no differences among treatment for BCS (Table 6). Throughout the experiment, heifers maintained BCS close to 3.0 with a tendency $(P=0.09)$ for BCS to decrease over time, indicating that heifers were not accumulating excess adipose tissue. These results are consistent with findings by Anderson et al. (2015a) who fed low-fat and traditional DDGS compared with a control diet.

\section{Rumen Fermentation}

Rumen fermentation characteristics are presented in Table 7. There was a treatment by week interaction for isobutyrate concentration, propionate molar percentage, and acetate to propionate ratio, and tendencies 
for a treatment by week interaction were observed for acetate, valerate, and total VFA concentrations. Propionate concentration linearly increased as the dietary concentration of DDGS increased, whereas butyrate concentration and acetate to propionate ratio linearly decreased with increasing dietary concentration of DDGS. The propionate molar percentage also increased, whereas acetate and butyrate molar percentages decreased. The shift in molar VFA concentrations is a result of differences in dietary forage concentrations, suggesting a shift in bacterial species population in the rumen. Acetate production within the rumen is the result of the fermentation of structural carbohydrates by cellulolytic bacteria, whereas propionate formation is due to the fermentation of nonstructural carbohydrates by amylolytic bacteria (Enjalbert et al., 1999). The decrease in acetate-to-propionate ratio as the concentration of DDGS increased is consistent with other studies that fed heifers diets differing in concentrate proportions (Lascano and Heinrichs, 2009; Suarez-Mena et al., 2015). This also suggests that heifers fed greater concentrate-to-forage ratios of DDGS may have more efficient rumen fermentation as shown by a greater proportion of propionate production. Production of propionate results in less carbon loss as methane or carbon dioxide compared with acetate (Fahey and Berger, 1988). This theory is also supported by increased gain:feed as DDGS was increased in the diet.

Rumen ammonia-N concentration linearly increased as the dietary concentration of DDGS increased. Suarez-Mena et al. (2015) fed increasing concentrations of DDGS in replacement of canola meal at 2 forage concentrations and found that $\mathrm{NH}_{3}-\mathrm{N}$ tended to be greater for high forage diets as the result of lower microbial activity for microbial protein synthesis. However, diets in that experiment had greater starch and NFC concentrations and lower $\mathrm{CP}$ than diets in the current experiment. Ammonia is used for protein synthesis within the rumen and accumulates when protein degradation exceeds microbial requirements (NRC, 2001). The supply of fermentable carbohydrates also can affect the assimilation of $\mathrm{N}$ by rumen bacteria (Nocek and Russell, 1988; Bach et al., 2005). Therefore, low dietary starch concentrations and the increased $\mathrm{CP}$ concentrations may explain the high rumen $\mathrm{NH}_{3}-\mathrm{N}$ among treatments. Research using lactating dairy cows has also shown that increasing the dietary $\mathrm{CP}$ results in increased concentrations of ruminal $\mathrm{NH}_{3}-\mathrm{N}$ (Hristov et al., 2004). Additionally, rumen fluid samples were taken at a single time point, approximately $4 \mathrm{~h}$ postfeeding, when $\mathrm{NH}_{3}-\mathrm{N}$ concentration are potentially at their greatest (Owens and Zinn, 1988). Further research with more frequent sample collections may be warranted to determine if rumen $\mathrm{NH}_{3}-\mathrm{N}$ concentrations fluctuate or if they remain high throughout the day when dairy heifers are limit-fed diets high in DDGS.

\section{Total-Tract Nutrient Digestion}

Total-tract nutrient digestibility is presented in Table 8. Digestibility of NDF and ADF was similar among treatments, whereas digestibility of DM, OM, and CP linearly increased with increasing concentrations of DDGS $(P<0.01)$. This is because grass hay has less TDN compared with DDGS (NRC, 2001). With greater DDGS, the greater amounts of fat consumed poten-

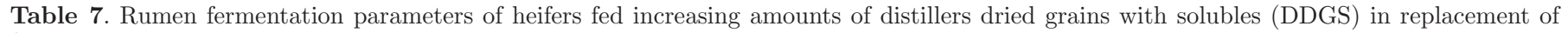
forage

\begin{tabular}{|c|c|c|c|c|c|c|c|c|c|}
\hline \multirow[b]{2}{*}{ Item } & \multicolumn{3}{|c|}{ Treatment $^{1}$} & \multirow[b]{2}{*}{ SEM } & \multicolumn{5}{|c|}{$P$-value ${ }^{2}$} \\
\hline & $30 \mathrm{DG}$ & $40 \mathrm{DG}$ & $50 \mathrm{DG}$ & & Trt & $\mathrm{Wk}$ & Trt $\times$ wk & $\mathrm{L}$ & $\mathrm{Q}$ \\
\hline $\mathrm{pH}$ & 6.67 & 6.54 & 6.52 & 0.087 & 0.42 & 0.10 & 0.46 & 0.22 & 0.60 \\
\hline $\mathrm{NH}_{3}-\mathrm{N}, \mathrm{mg} / \mathrm{dL}$ & 15.4 & 17.1 & 19.3 & 1.03 & 0.03 & 0.52 & 0.25 & $<0.01$ & 0.84 \\
\hline Acetate, $\mathrm{m} M$ & 43.4 & 41.9 & 41.7 & 1.38 & 0.63 & 0.29 & 0.07 & 0.38 & 0.70 \\
\hline Propionate, $\mathrm{m} M$ & 18.1 & 19.9 & 22.6 & 1.03 & 0.01 & $<0.01$ & 0.15 & $<0.01$ & 0.73 \\
\hline Isobutyrate, $\mathrm{m} M$ & 0.87 & 0.95 & 0.95 & 0.037 & 0.23 & 0.37 & 0.03 & 0.15 & 0.37 \\
\hline Butyrate, $\mathrm{m} M$ & 8.88 & 8.58 & 7.26 & 0.420 & 0.02 & 0.22 & 0.22 & $<0.01$ & 0.32 \\
\hline Isovalerate, $\mathrm{m} M$ & 0.48 & 0.58 & 0.50 & 0.029 & 0.06 & 0.20 & 0.53 & 0.72 & 0.02 \\
\hline Valerate, $\mathrm{m} M$ & 1.33 & 1.30 & 1.24 & 0.054 & 0.53 & 0.07 & 0.05 & 0.27 & 0.82 \\
\hline Total VFA, $\mathrm{m} M$ & 73.1 & 73.2 & 74.2 & 2.43 & 0.93 & 0.09 & 0.08 & 0.73 & 0.88 \\
\hline Acetate, mmol/100 mmol & 59.4 & 57.3 & 56.2 & 0.55 & $<0.01$ & 0.03 & 0.27 & $<0.01$ & 0.52 \\
\hline Propionate, mmol/100 mmol & 24.7 & 26.9 & 30.4 & 0.81 & $<0.01$ & 0.05 & 0.03 & $<0.01$ & 0.54 \\
\hline Isobutyrate, mmol/100 mmol & 1.20 & 1.31 & 1.28 & 0.042 & 0.19 & 0.48 & 0.21 & 0.18 & 0.21 \\
\hline Butyrate, mmol/100 mmol & 12.2 & 11.9 & 9.8 & 0.50 & $<0.01$ & 0.64 & 0.31 & $<0.01$ & 0.19 \\
\hline Isovalerate, mmol/100 mmol & 0.67 & 0.80 & 0.68 & 0.038 & 0.05 & 0.03 & 0.38 & 0.80 & 0.02 \\
\hline Valerate, mmol/100 mmol & 1.80 & 1.78 & 1.67 & 0.058 & 0.24 & 0.14 & 0.22 & 0.12 & 0.50 \\
\hline Acetate:propionate & 2.44 & 2.18 & 1.90 & 0.075 & $<0.01$ & $<0.01$ & 0.02 & $<0.01$ & 0.86 \\
\hline
\end{tabular}

${ }^{1} 30 \%$ dietary inclusion rate of DDGS (30DG), 40\% dietary inclusion rate of DDGS (40DG), 50\% dietary inclusion rate of DDGS (50DG).

${ }^{2}$ Significance of effects for treatment (Trt), week (wk), treatment $\times$ week (Trt $\times$ wk), and linear $(\mathrm{L})$ and quadratic $(\mathrm{Q})$ orthogonal contrasts. 
Table 8. Total-tract digestibility of nutrients for heifers fed increasing amounts of distillers dried grains with solubles (DDGS) in replacement of grass hay

\begin{tabular}{|c|c|c|c|c|c|c|c|}
\hline \multirow[b]{2}{*}{ Item, \% } & \multicolumn{3}{|c|}{ Treatment $^{1}$} & \multirow[b]{2}{*}{ SEM } & \multicolumn{3}{|c|}{$P$-value ${ }^{2}$} \\
\hline & $30 \mathrm{DG}$ & $40 \mathrm{DG}$ & $50 \mathrm{DG}$ & & Trt & $\mathrm{L}$ & $\mathrm{Q}$ \\
\hline DM & 64.7 & 68.3 & 72.9 & 1.92 & $<0.01$ & $<0.01$ & 0.71 \\
\hline $\mathrm{OM}$ & 66.4 & 69.8 & 74.0 & 1.92 & $<0.01$ & $<0.01$ & 0.77 \\
\hline CP & 73.7 & 79.5 & 86.0 & 1.90 & $<0.01$ & $<0.01$ & 0.80 \\
\hline NDF & 54.6 & 57.1 & 58.6 & 3.75 & 0.27 & 0.11 & 0.82 \\
\hline $\mathrm{ADF}$ & 50.8 & 52.4 & 53.4 & 2.17 & 0.69 & 0.39 & 0.90 \\
\hline
\end{tabular}

tially could interfere with fermentation because of the effects of unsaturated lipids on microbial growth and negatively affected the digestibility of nonlipid energy sources (Jenkins, 1993; NRC, 2001). However, even with a $50 \%$ inclusion rate of DDGS in the diet, total diet EE concentration was less than $8 \%$, which is thought to be the upper limit before fat concentration begins to have negative effects on the rumen degradation of fiber and DM (Palmquist, 1994; NRC, 2001). Anderson et al. (2015a) speculated that the fat from DDGS is bound within the feed particle and had less severe effects on digestion of nutrients because it is slowly introduced in the rumen.

The total-tract digestibility of $\mathrm{CP}$ in the current study is consistent with previous research (Anderson et al., 2015a), who found that when dairy heifers were fed full-fat DDGS at $33 \%$ of diet DM, the total-tract digestibility of CP was $73 \%$. In the current experiment, the total-tract digestibility of $\mathrm{CP}$ was $86 \%$ for the 50DG treatment, which is greater than that reported by Anderson et al. (2015a); however, the 30DG treatment was similar.

\section{CONCLUSIONS}

In agreement with our hypothesis, limit-feeding diets containing DDGS up to $50 \%$ of DM maintained growth performance of dairy heifers based on BW, ADG, and frame growth. No differences were observed in BW, and ADG was maintained among treatments. However, ADG was greater than NRC (2001) predictions for all treatments, but heifers did not accumulate excess adipose tissue as demonstrated by a tendency for decreased BCS during the course of the study. In addition, increasing the dietary concentration of DDGS in replacement of forage increased gain:feed and nutrient digestibility of DM, OM, and CP. Overall, this research indicated that DDGS can be fed as part of limit-fed rations for growing dairy heifers at up to $50 \%$ of dietary DM and result in increased feed efficiency and main- tained growth performance compared with inclusion at 30 or $40 \%$ of diet DM.

\section{ACKNOWLEDGMENTS}

Funding for this research was provided by the Minnesota Corn Research and Promotion Council (Shakopee) and the Minnesota Agricultural Utilization Research Institute (Crookston) with support provided from the South Dakota Agricultural Experiment Station (Brookings). The authors also thank fellow graduate students and farm personnel in the Dairy Science Department at South Dakota State University (Brookings), at the time this study was conducted, for their help with sampling and animal care. This research contributes to the goals of the USDA North Central Cooperative Research Project NC-2042: Management Systems to Improve Economic and Environmental Sustainability of Dairy Enterprises.

\section{REFERENCES}

Anderson, J. L., K. F. Kalscheur, A. D. Garcia, and D. J. Schingoethe. 2015a. Feeding fat from distillers dried grains with solubles to dairy heifers: I. Effects on growth performance and total-tract digestibility of nutrients. J. Dairy Sci. 98:5699-5708.

Anderson, J. L., K. F. Kalscheur, A. D. Garcia, and D. J. Schingoethe. 2015b. Short communication: Feeding fat from distillers dried grains with solubles to dairy heifers: III. Effects on post-trial reproductive and lactation performance. J. Dairy Sci. 98:5720-5725.

Anderson, J. L., K. F. Kalscheur, A. D. Garcia, D. J. Schingoethe, D P. Casper, and D. H. Kleinschmit. 2015c. Ensiling characteristics of distillers wet grains with cornstalks and determination of the feeding potential for dairy heifers. Prof. Anim. Sci. 31:359-367.

Anderson, J. L., K. F. Kalscheur, A. D. Garcia, D. J. Schingoethe, and A. R. Hippen. 2009. Ensiling characteristics of wet distillers grains mixed with soybean hulls and evaluation of the feeding value for growing Holstein heifers. J. Anim. Sci. 87:2113-2123.

Anderson, J. L., D. J. Schingoethe, K. F. Kalscheur, and A. R. Hippen. 2006. Evaluation of dried and wet distillers grains included at two concentrations in the diets of lactating dairy cows. J. Dairy Sci. 89:3133-3142.

AOAC International. 1995. Official Methods of Analysis. 16th ed. AOAC International, Arlington, VA.

AOAC International. 2002. Official Methods of Analysis. 17th ed. Association of Official Analytical Chemists, Gaithersburg, MD. 
Bach, A., S. Calsamiglia, and M. D. Stern. 2005. Nitrogen metabolism in the rumen. J. Dairy Sci. 88:E9-E21.

Bach Knudsen, K. E. 1997. Carbohydrate and lignin contents of plant materials used in animal feeding. Anim. Feed Sci. Technol. 67:319 338.

Chaney, A. L., and E. P. Marbach. 1962. Modified reagents for determination of urea and ammonia. Clin. Chem. 8:130-132.

Enjalbert, F., J. E. Garrett, R. Moncoulon, C. Bayourthe, and P. Chicoteau. 1999. Effects of yeast culture (Saccharomyces cerevisiae) on ruminal digestion in non-lactating dairy cows. Anim. Feed Sci. Technol. 76:195-206.

Fahey, G. C., and L. L. Berger. 1988. Carbohydrate nutrition of ruminants. Pages 269-295 in The Ruminant Animal: Digestive Physiology and Nutrition. D. C. Church, ed. Prentice Hall Inc., Upper Saddle River, NJ.

Hoffman, P. C. 1997. Optimum body size of Holstein replacement heifers. J. Anim. Sci. 75:836-845.

Hoffman, P. C., C. R. Simson, and M. Wattiaux. 2007. Limit-feeding of gravid Holstein heifers: Effect on growth, manure nutrient excretion, and subsequent early lactation performance. J. Dairy Sci. 90:946-954.

Hristov, A. N., R. P. Etter, J. K. Ropp, and K. L. Grandeen. 2004. Effect of dietary crude protein level and degradability on ruminal fermentation and nitrogen utilization in lactating dairy cows. J. Anim. Sci. 82:3219-3229.

Jenkins, T. C. 1993. Lipid metabolism in the rumen. J. Dairy Sci. $76: 3851-3863$

Klopfenstein, T. J., G. E. Erickson, and V. R. Bremer. 2008. Board invited review: Use of distillers by-products in the beef cattle feeding industry. J. Anim. Sci. 86:1223-1231.

Kutner, M. H., C. J. Nachtsheim, and J. Neter. 2004. Applied Linear Regression Models. 4th ed. The McGraw-Hill Companies Inc., New York, NY.

Lascano, G. J., and A. J. Heinrichs. 2009. Rumen fermentation pattern of dairy heifers fed restricted amounts of low, medium, and high concentrate diets without and with yeast culture. Livest. Sci. 124:48-57.

Littell, R. C., G. A. Milliken, W. W. Stroup, R. D. Wolfinger, and O. Schabenberger. 2006. SAS for Mixed Models, 2nd ed. SAS Institute, Cary, NC.

Merchen, N. R. 1988. Digestion, Absorption and Excretion in Ruminants. Pages 182-189 in The Ruminant Animal: Digestive Physiology and Nutrition. D. C. Church, ed. Prentice Hall Inc., Upper Saddle River, NJ.

NRC. 2001. Nutrient Requirements of Dairy Cattle. 7th rev. ed. Natl. Acad. Press, Washington, DC.
Nocek, J. E., and J. B. Russell. 1988. Protein and energy as an integrated system. Relationship of ruminal protein and carbohydrate availability to microbial synthesis and milk production. J. Dairy Sci. 71:2070-2107.

Owens, F. N., and R. Zinn. 1988. Protein metabolism of ruminant animals. Pages 227-249 in The Ruminant Animal: Digestive Physiology and Nutrition. D. C. Church, ed. Prentice Hall Inc., Upper Saddle River, NJ.

Palmquist, D. L. 1994. The role of dietary fats in efficiency of ruminants. J. Nutr. 124:1377S-1382S.

Robertson, J. B., and P. J. Van Soest. 1981. The detergent system of analysis and its application to human foods. Pages 123-158 in The Analysis of Dietary Fiber in Food. W. P. T. James and O. Theander, ed. Marcel Dekker Inc., New York, NY.

Schingoethe, D. J., K. F. Kalscheur, A. R. Hippen, and A. D. Garcia. 2009. Invited review: The use of distillers products in dairy cattle diets. J. Dairy Sci. 92:5802-5813.

Schroer, R. C., T. D. Nennich, T. S. Dennis, M. M. Schutz, S. S. Donkin, and D. Little. 2014. Intake and growth of prepubertal dairy heifers fed reduced-fat dried distillers grains. Prof. Anim. Sci. 30:93-98.

Suarez-Mena, F. X., G. J. Lascano, D. E. Rico, and A. J. Heinrichs. 2015. Effect of forage level and replacing canola meal with dry distillers grains with solubles in precision-fed heifer diets: Digestibility and rumen fermentation. J. Dairy Sci. 98:8054-8065.

Thiex, N. 2009. Evaluation of analytical method for the determination of moisture, crude protein, crude fat, and crude fiber in distillers dried grains with solubles. J. AOAC Int. 92:61-73.

Van Soest, P. J., J. B. Robertson, and B. A. Lewis. 1991. Methods for dietary fiber, neutral detergent fiber, and non-starch polysaccharides in relation to animal nutrition. J. Dairy Sci. 74:3583-3597.

Wildman, E. E., G. M. Jones, P. E. Wagner, R. L. Boman, H. F. Troutt Jr., and T. N. Lesch. 1982. A dairy cow body condition scoring system and its relationship to selected production characteristics. J. Dairy Sci. 65:495-501.

Zanton, G. I., and A. J. Heinrichs. 2005. Meta-analysis to assess effect of prepubertal average daily gain of Holstein heifers on firstlactation production. J. Dairy Sci. 88:3860-3867.

Zanton, G. I., and A. J. Heinrichs. 2007. The effects of controlled feeding of a high-forage or high-concentrate ration on heifer growth and first-lactation milk production. J. Dairy Sci. 90:3388-3396.

Zanton, G. I., and A. J. Heinrichs. 2009. Digestion and nitrogen utilization in dairy heifers limit-fed a low or high forage ration at four levels of nitrogen intake. J. Dairy Sci. 92:2078-2094. 